\title{
TINGKAT EFISIENSI DAN PRODUKTIVITAS LEMBAGA ZAKAT DI INDONESIA
}

\author{
Salman Al Parisi \\ SMART Consulting \\ salman.al.farisi.tazkia@gmail.com
}

\begin{abstract}
This study aimed to measure the efficiency and productivity of five zakah institutions. Calculation of efficiency level in this study are relative, not absolute. This Study consists of two methods: Data Envelopment Analysis (DEA), and Malmquist Productivity Index (MPI). There are 5 research objects, namely DD, BAZNAS, PKPU, YBM BRI and RZI with annual data 2005 to 2014. Furthermore, the lowest relative efficiencies level is DD (2010) amounted to 9.63\%. In addition, approximately $80 \%$ of five OPZs increased the productivity. In the general, the main factor of inefficient of five zakat institutions from 2005 to 2014 was caused by distribution of zakah to ashnaf which still not optimal, then it cannot solve the poverty rate. Furthermore, it needs to increase collection and distribution of zakah fund amounted to $31.53 \%$ and $47.87 \%$. Besides that it needs to decrease cost of socialization and operational cost amounted to $11.81 \%$ and $8.79 \%$.
\end{abstract}

Keywords: zakah institution, data envelopment analysis, malmquist productivity index

\begin{abstract}
Abstrak
Penelitian ini bertujuan untuk mengukur efisiensi dan produktivitas serta menentukan faktor- faktor yang mempengaruhi tingkat efisiensi 5 Lembaga Zakat Indonesia. Penghitungan tingkat efisiensi dalam penelitian ini bersifat relatif, bukan absolut. Terdiri dari 2 metode yaitu: Data Envelopment Analysis (DEA) dan Malmquist Productivity Index (MPI). Terdapat 5 objek penelitian yaitu DD, BAZNAS, PKPU, YBM BRI dan Rumah Zakat Indonesia dengan data tahunan 2005 sampai 2014. OPZ yang paling rendah tingkat efisiensi relatifnya adalah DD (2010) sebesar 9.63\%. Selain itu sekitar 80\% dari total 5 OPZ mengalami peningkatan produktivitas. Secara umum, faktor utama inefisiensi Organisasi Pengelola Zakat (dalam pengamatan) dari tahun 2005 hingga 2014 disebabkan oleh penyaluran dana zakat terhadap ashnaf yang masih kurang optimal, sehingga belum mampu menyelesaikan problematika kemiskinan. Dengan rincian dana penyaluran perlu ditingkatkan hingga 47.87\%, kemudian dana penerimaan hingga 31.53\% dan perlu mengurangi biaya sosialisasi hingga 11.81\% dan biaya operasional hingga $8.79 \%$.
\end{abstract}

Kata Kunci: lembaga zakat, data envelopment analysis, malmquist productivity index

Diterima: 11 September 2016; Direvisi: 31 Januari 2017; Disetujui: 11 Februari 2017 


\section{PENDAHULUAN}

Zakat merupakan rukun Islam ketiga yang menjadi salah satu fondasi penting dalam Islam. Oleh karena itu, sebagai salah satu dari rukun Islam, maka zakat hukumnya wajib bagi setiap Muslim yang telah memenuhi syarat. Berbeda dengan rukun Islam yang lain yang lebih cenderung sebagai rukun pribadi, zakat dapat disebut sebagai "rukun masyarakat". Perintah zakat juga dapat dipahami sebagai satu kesatuan sistem yang tak terpisahkan dalam pencapaian kesejahteraan sosialekonomi dari aspek al-„,adalah al-ijtima“iyah (keadilan sosial). Implikasi zakat dapat meminimalisir kesenjangan sosial dalam masyarakat, sebab zakat diharapkan dapat meningkatkan dan menumbuhkan perekonomian baik individu maupun masyarakat. Hal ini perlu dibuktikan dengan logika ekonomi (kebijakan fiskal), karena masih banyak orang yang menganggap bahwa zakat merupakan faktor pengurang pendapatan kena pajak seseorang. Untuk itu, para ekonom Islam dan ahli hukum Islam harus mampu menjelaskan dengan nalar yang dapat diterima oleh masyarakat yang lebih mengedepankan rasionalitas (masyarakat sekuler) (Audi, 2000).

Zakat merupakan stimulus dalam perekonomian sehingga memunculkan kekuatan baru dalam penghimpunan investasi yang signifikan sehingga akan mendorong peningkatan produksi dalam siklus perekonomian suatu daerah. Bahkan secara makro zakat akan dapat meningkatkan agregat demand karena meningkatnya purchasing power (daya beli) masyarakat atas barang-barang dan jasa. Ketika zakat diimplementasikan secara sistem pengelolaan yang baik, dalam artian bahwa zakat adalah peraturan yang mengikat dalam diri setiap muslim dengan peran pemerintah sebagai regulator sekaligus badan amil zakatnya, maka secara pasti akan menyebabkan munculnya lapangan kerja yang sangat luas sehingga setiap warga negara mempunyai lahan pekerjaan dan otomatis akan terjadi migrasi pengangguran menjadi karyawan dalam jumlah yang sangat besar.

Dalam pengelolaan penggunaan dana zakat, yang terpenting dan tidak boleh dilupakan adalah peran amil zakat (baca: Organisasi Pengelola Zakat) selaku pengemban amanah pengelolaan dana-dana zakat itu. Jika para amil zakatnya baik dalam pengelolaannya, maka dapat berpengaruh signifikan positif terhadap ashnaf 
mustahik lainnya. Tapi jika para amil zakat tidak baik dalam pengelolaannya, maka diduga hak ashnaf mustahik yang lain tidak akan terpenuhi, itulah nilai esensi strategisnya amil zakat. Dengan kata lain, hal terpenting dari zakat adalah bagaimana mengelola dalam menggunakan dana zakat (manajemennya) sehingga dapat mencapai efisiensi dan produktivitas yang optimal. Noor, dkk (2012) pengelolaan kinerja dan sistem pengukuran harus dikembangkan pada organisasi pengelola zakat. Hal ini sebagai upaya untuk mengawasi akuntabilitas dari lembaga pengelola zakat.

Efisiensi merupakan suatu konsep yang secara umum telah digunakan dalam mengukur kinerja suatu perusahaan. Menurut Srivastava (1999), suatu perusahaan dikatakan efisien apabila perusahaan tersebut dapat meminimalkan biaya dalam menghasilkan output tertentu atau dapat memaksimalkan keuntungannya dengan menggunakan kombinasi input yang ada. Efisiensi juga dapat diartikan sebagai kemampuan untuk memperoleh output yang tetap dengan menggunakan sumberdaya dalam jumlah yang minimal (Daraio dan Simar, 2007).

Selain efisiensi, ukuran kinerja lainnya ialah produktivitas. Produktivitas adalah perbandingan antara nilai barang yang dihasilkan dari suatu aktivitas produksi dengan biaya-biaya yang dikeluarkan untuk menghasilkan barang tersebut dalam suatu periode tertentu.

Terdapat tiga hal penting yang harus diketahui dari pengukuran produktivitas, yaitu: Pertama, pengukuran produktivitas akan berdampak pada neraca. Kedua, pengukuran produktivitas akan berdampak pada laporan laba-rugi. Aliran bahan baku yang kemudian diproses dalam proses produksi akan berdampak pada kedua hal tersebut di atas. Ketiga, pengukuran produktivitas haruslah memungkinkan untuk diterapkan serta fleksibel terhadap perubahan salah satu variabel. Pengukuran produktivitas seharusnya dapat mencerminkan kondisi perusahaan di masa yang akan datang dimana hal ini tidak dapat diketahui dari laporan neraca dan laba-rugi. Laba yang dicapai oleh perusahaan mungkin tinggi dan modal yang digunakan berada pada kondisi yang baik, tetapi apabila tidak disertai peningkatan produktivitas maka perusahaan tidak akan bisa bertahan dalam jangka panjang. Pengukuran produktivitas yang dilakukan oleh perusahaan 
mencerminkan peningkatan aktivitas operasional perusahaan terlepas dari kondisi perekonomian secara makro.

Penelitian ini bertujuan meneliti pengukuran efisiensi dan produktivitas Organisasi Pengelolaan Zakat (OPZ) selama periode 2005 - 2014, bagaimana posisi tingkat efisiensi masing-masing $\mathrm{OPZ}$ dari tahun ke tahun dan bagaimana distribusi skornya. Bagaimana pula kondisi return to scale tiap DMU dan potensi-potensi pengembangan untuk OPZ yang belum efisien. Kemudian apa saja DMU yang menjadi rujukan (benchmark) untuk DMU lainnya. Dan terakhir bagaimana tingkat produktivitas dari masing- masing OPZ pada tahun 2012-2013 untuk dapat dijadikan sebagai kebijakan pada OPZ di Indonesia agar dapat lebih efisien dan produktif dalam menghimpun dan menyalurkan dana zakat kepada para mustahik.

\section{METODE}

Penelitian ini menggunakan data sekunder selama periode 2005-2014 yang sudah dipublikasikan sebagai data pokok, seperti laporan keuangan, neraca, dan laporan arus kas. Data pokok tersebut dapat diperoleh dari publikasi yang diterbitkan oleh masing-masing OPZ. Namun, karena keterbatasan data yang tersedia, Baznas dari tahun 2005-2013 dan Rumah Zakat mulai 2012-2014. Sementara data PKPU relatif lengkap dari periode tahun 2007-2014. Adapun DD memiliki data dari 2010-2013 dan YBM BRI dari tahun 2012-2014.

Kajian dalam penelitian ini memfokuskan pada pengukuran tingkat efisiensi dari 5 (lima) Organisasi Pengelola Zakat nasional. Kelima OPZ tersebut adalah Badan Amil Zakat Nasional (Baznas), Pos Keadilan Peduli Umat (PKPU), Rumah Zakat Indonesia (RZI), Dompet Dhuafa (DD) dan YBM BRI. Alasan pemilihan kelima OPZ itu adalah karena mereka relatif secara konsisten mempublikasikan laporan keuangan tahunannya, dibanding OPZ lain. Alasan yang lain adalah kelima OPZ tersebut cukup berhasil menghimpun dana cukup besar dari masyarakat.

Teknik analisis yang akan dipergunakan dalam penelitian ini untuk mengukur tingkat efisiensi dan produktivitas lembaga zakat ialah Data Envelopment Analysis (DEA) dan Malmquist Productivity Index. Adapun software yang digunakan yaitu Banxia Frontier dan DEAP. 


\section{HASIL DAN PEMBAHASAN}

\section{Hasil}

Pada Tabel 1 menunjukkan nilai efisiensi masing- masing OPZ, dapat diketahui bahwa OPZ yang efisien (Constant 100\%) pada tahun 2014 adalah YBM BRI dan PKPU. Sedangkan OPZ yang efisien pada tahun 2013 adalah YBM BRI. Kemudian pada tahun 2012, OPZ yang efisien yaitu YBM BRI, dan pada tahun 2011, OPZ yang efisien yaitu PKPU. Sehingga dapat disimpulkan bahwa YBM BRI dapat mempertahankan tingkat efisien dari tahun ke tahun secara gradual dari tahun 2012 hingga tahun 2014 jika dibandingkan dengan OPZ lainnya dalam pengamatan ini. Berdasarkan informasi tabel tersebut, OPZ yang paling rendah angka efisiensinya adalah DD di tahun 2010 sebesar 9.63\%. Hal ini tentunya dapat menjadi pertimbangan bagi OPZ yang belum efisien untuk dapat meningkatkan efisiensi teknisnya (pure technical efficiency).

Tabel 1. Skor Efisiensi Organisasi Pengelola Zakat

\begin{tabular}{|c|c|c|c|}
\hline No & Nama & Skor & Skala \\
\hline 1 & 2012 YBM BRI & 100 & Constant \\
\hline 2 & 2011 PKPU & 100 & Constant \\
\hline 3 & 2013 YBM BRI & 100 & Constant \\
\hline 4 & 2014 YBM BRI & 100 & Constant \\
\hline 5 & 2014 PKPU & 100 & Constant \\
\hline 6 & 2013 PKPU & 91.48 & Increasing \\
\hline 7 & 2012 PKPU & 79.73 & Increasing \\
\hline 8 & 2005 Baznas & 69.64 & Decreasing \\
\hline 9 & 2008 Baznas & 61.65 & Decreasing \\
\hline 10 & 2010 PKPU & 55.03 & Increasing \\
\hline 11 & $2011 \mathrm{DD}$ & 48.01 & Increasing \\
\hline 12 & 2013 DD & 47.31 & Increasing \\
\hline 13 & 2012 Baznas & 47.01 & Decreasing \\
\hline 14 & 2012 Rumah Zakat & 46.97 & Increasing \\
\hline 15 & 2009 Baznas & 46.03 & Decreasing \\
\hline 16 & 2007 Baznas & 40.85 & Decreasing \\
\hline 17 & 2006 Baznas & 38.99 & Decreasing \\
\hline 18 & 2012 DD & 35.12 & Increasing \\
\hline 19 & 2008 PKPU & 30.45 & Decreasing \\
\hline 20 & 2014 Rumah Zakat & 29.13 & Increasing \\
\hline 21 & 2013 Rumah Zakat & 28.21 & Increasing \\
\hline 22 & 2010 Baznas & 26.82 & Decreasing \\
\hline 23 & 2007 PKPU & 25.54 & Decreasing \\
\hline 24 & 2011 Baznas & 22.25 & Decreasing \\
\hline 25 & 2009 PKPU & 21.22 & Decreasing \\
\hline 26 & 2013 Baznas & 19.33 & Decreasing \\
\hline 27 & $2010 \mathrm{DD}$ & 9.63 & Increasing \\
\hline
\end{tabular}


Di samping itu, jika melihat OPZ yang belum efisien dapat diketahui dari tabel di bawah ini bahwa DMU yang inefisien terbagi menjadi dua bagian yaitu Increasing Return to Scale (IRS) dan Decreasing Return to Scale (DRS). Adapun OPZ yang termasuk dalam kelompok increasing yaitu PKPU (2010), (2012) dan (2013), DD (2010), (2011), (2012), dan (2013), serta Rumah Zakat (2012), (2013), (2014). Untuk mencapai tingkat efisien keempat OPZ tersebut, maka masih dapat diusahakan dengan melihat nilai potential improvement- nya. Berbeda halnya dengan OPZ yang termasuk decreasing yaitu Baznas (2005), (2006), (2007), (2008), (2009), (2010), (2011), (2012), (2013) dan PKPU (2007), (2008), (2009).

Berdasarkan hasil olahan data dapat diketahui jumlah OPZ yang efisien sempurna (100\%) adalah sebanyak 5 OPZ. Selain itu, dapat diketahui bahwa unit bisnis terbanyak berada dalam kondisi efisiensi 21\%-30\% yaitu sebanyak 7 DMU, sedangkan yang paling sedikit adalah unit bisnis dengan tingkat efisiensi 0\%-10\%, 11\%-20\%, 51\%-60\%, 71\%-80\%, dan 91\%-99.9\% yaitu masing- masing 1 DMU.

Total Potential Improvement digunakan untuk mengetahui faktor inefisiensi OPZ dalam pengamatan ini, grafik di bawah ini menunjukkan informasi total potential improvement yang dapat memberikan gambaran umum terkait inefisiensi OPZ. Grafik total potential improvement menyebutkan bahwa secara industry, supaya efisien maka hendaknya OPZ yang tidak efisien mengurangi beban sosialisasi hingga $11.81 \%$, dan biaya operasional hingga $8.79 \%$. Sedangkan untuk dana penerimaan perlu ditingkatkan hingga 31.53\% dan dana penyaluran hingga 47.87\% agar tercapai tingkat efisiensi yang optimal.

Berdasarkan hasil perhitungan analisis frontier menunjukkan bahwa pada tahun 2014 Organisasi Pengelola Zakat (OPZ) yang paling banyak dirujuk adalah PKPU dirujuk sebanyak 9 DMU dan YBM BRI dirujuk sebanyak 7 DMU. Sedangkan pada tahun 2013, OPZ yang paling banyak dirujuk adalah YBM BRI dirujuk sebanyak 7 DMU. Begitupun pada tahun 2012, OPZ yang paling banyak dirujuk adalah YBM BRI dirujuk sebanyak 13 DMU. Dan pada tahun 2011, OPZ yang paling banyak dirujuk adalah PKPU dirujuk sebanyak 1 DMU.

Penelitian ini mencoba menganalisis model CCR sebagai model dasar dalam DEA untuk melihat tingkat efisiensi OPZ di Indonesia untuk periode 2005-2014. 
Selanjutnya indeks Malmquist digunakan untuk melihat tingkat produktivitas dari OPZ, baik dari sisi perubahan efisiensinya maupun perubahan teknologi. Hasil yang diperoleh dari skor indeks Malmquist (TFP Change) menunjukkan bahwa 4 OPZ dari total 5 OPZ mengalami peningkatan produktivitas, atau sekitar $80 \%$ dari keseluruhan OPZ yang diobservasi. Ini ditandai dengan skor perubahan TFP lebih dari 1.

Tabel 2. Tingkat Produktivitas OPZ di Indonesia 2012-2013

\begin{tabular}{lccccc}
\hline \multicolumn{1}{c}{ DMU } & EFFCH & TECH & PE Change & $\begin{array}{c}\text { Ec.Scale } \\
\text { Change }\end{array}$ & TFP Change \\
\hline YBM BRI & 1.000 & 4.893 & 1.000 & 1.000 & 4.893 \\
RZI & 1.000 & 1.227 & 1.000 & 1.000 & 1.227 \\
PKPU & 1.000 & 2.441 & 1.000 & 1.000 & 2.441 \\
BAZNAS & 1.000 & 2.530 & 1.000 & 1.000 & 2.530 \\
DD & 0.730 & 0.981 & 0.855 & 0.853 & 0.845 \\
\hline
\end{tabular}

Pembahasan

Efisiensi adalah indikator dari keberhasilan kegiatan produktif. Efisiensi adalah parameter untuk mengukur kinerja, baik kinerja pada tingkat pusat pertanggungjawaban, kinerja manajerial, maupun kinerja ekonomi suatu perusahaan. Pada tingkat perusahaan, usaha meningkatkan efisiensi biasanya dikaitkan dengan biaya yang lebih kecil untuk memperoleh hasil tertentu, atau dengan biaya tertentu dapat diperoleh hasil yang lebih banyak.

Akbar (2009) dalam penelitiannya terhadap 9 organisasi pengelola zakat menemukan bahwa efisiensi pada tahun 2005 masih lebih baik dibandingkan dengan tahun 2006 dan 2007 baik secara teknis (94.52\%), skala (75\%), dan keseluruhan (71.27\%). Penyebab utama munculnya inefisiensi adalah dana tersalurkan dan dana terhimpun yang menyumbang 43.1\% dan 36\%. Sedangkan pengukuran dengan orientasi input menyatakan bahwa sumber inefisiensi adalah biaya operasional lain sebesar $34.9 \%$ dan biaya sosialisasi sebesar $31.1 \%$. Rusydiana dan Al Farisi (2016) menemukan bahwa dari tiga organisasi pengelola zakat terdapat 12 unit pengambil keputusan yang efisiensi dan 6 unit pengambil keputusan yang tidak efisien.

Wahab dan Rahman (2012) mengukur 14 lembaga keagamaan negara di 
Malaysia. Hasil penelitiannya menunjukkan bahwa produktivitas faktor total telah meningkat untuk keseluruhan industri serta perubahan teknis lebih besar dibandingkan perubahan efisiensi. Wahab dan Rahman (2013) dalam penelitiannya menyatakan bahwa produktivitas faktor total dari 14 lembaga zakat di Malaysia cenderung meningkat sebesar $2.4 \%$ selama masa observasi pengamatan. Selain itu terdapat beberapa faktor yang mempengaruhi tingkat efisiensi lembaga zakat di Malaysia, yaitu: sistem pembayaran zakat, sistem komputerisasi zakat, struktur organisasi, komite audit, dan desentralisasi. Wahab dan Rahman (2011) telah mengidentifikasi beberapa metode yang tepat untuk mengevaluasi efisiensi dan tata kelola pada lembaga zakat. Hal ini sebagai upaya untuk meningkatkan kinerja dari organisasi pengelola zakat terutama dari aspek efisiensi.

Avenzora (2008), menyatakan pada dasarnya produktivitas merupakan hubungan antara output dan input dalam sebuah produksi. Produktivitas dapat diukur secara parsial maupun total, produktivitas parsial merupakan hubungan antara output dengan satu input seperti produktivitas tenaga kerja yang menunjukkan rata- rata output per tenaga kerja atau produktivitas kapital yang menggambarkan rata- rata output per kapital. Produktivitas total atau Total Factor Productivity (TFP), mengukur hubungan antara output dengan beberapa input agregat, jika rasio meningkat berarti lebih banyak output dapat diproduksi menggunakan jumlah input tertentu atau sejumlah output dapat diproduksi dengan menggunakan lebih sedikit input.

\section{SIMPULAN}

Terdapat 5 Unit Pengambil Keputusan (Decision Making Unit/DMU) yang efisien sempurna (100\%). Dan yang inefisien sebanyak 22 DMU, terdiri dari 10 DMU (kondisi IRS) dan 12 DMU (kondisi DRS). OPZ yang paling tidak efisien adalah DD (2010) sebesar 9.63\% tingkat efisiensinya. Secara umum, faktor utama inefisiensi Organisasi Pengelola Zakat (dalam pengamatan) dari tahun 2005 hingga 2014 disebabkan oleh penyaluran dana zakat terhadap ashnaf yang masih kurang optimal, sehingga belum mampu menyelesaikan problematika kemiskinan. Dengan rincian dana penyaluran perlu ditingkatkan hingga 47.87\%, kemudian dana penerimaan hingga $31.53 \%$ dan perlu mengurangi biaya sosialisasi hingga $11.81 \%$ 
dan biaya operasional hingga 8.79\%. Selain itu, hasil yang diperoleh dari skor indeks Malmquist (TFP Change) menunjukkan bahwa 4 OPZ dari total 5 OPZ mengalami peningkatan produktivitas, atau sekitar $80 \%$ dari keseluruhan OPZ yang diobservasi. Ini ditandai dengan skor TFP Change lebih dari 1.

\section{PUSTAKA ACUAN}

Akbar, N. (2009). Analisis Efisiensi Organisasi Pengelola Zakat Nasional dengan Pendekatan Data Envelopment Analysis. TAZKIA Islamic Finance and Business Review. Vol. 4, No. 2: 760-784.

Audi, R. (2000). Religious Commitment and Secular Reason. Cambridge: Cambridge University Press.

Avenzora, A. \& J.P. Moeis. (2008). Analisis Produktivitas dan Efisiensi Industri Tekstil dan Produk Tekstil di Indonesia Tahun 2002-2004. (Tesis Tidak Dipublikasikan). Jakarta: Universitas Indonesia

Daraio C \& L. Simar. (2007). Advance Robust and Non Parametric Methods in Efficiency Analysis. Methodology and Applications. New York: Springer

Lestari, A. (2015). Efisiensi Kinerja Keuangan Badan Amil Zakat Daerah (BAZDA): Pendekatan Data Envelopment Analysis (DEA). Jurnal Ekonomi dan Studi Pembangunan. Vol. 16, No. 2: 177-187.

Noor, A.H.M, dkk. (2012). Assesing Performance of Nonprofit Organization: A Framework for Zakat Institutions. British Journal of Economics, Finance, and Management Sciences. Vol. 5 (1): 12-22.

Rusydiana, A.S. \& S. Al Farisi. The Efficiency of Zakah Institutions Using Data Envelopment Analysis. Al-Iqtishad: Jurnal Ilmu Ekonomi Syariah (Journal of Islamic Economics). Vol. 8 (2): 213-226.

Srivastava, P. (1999). Size, Efficiency and Financial Reforms In Indian Banking. Working Paper No. 49. Indian Council For Research On International Economic Relations.

Wahab, N.A. \& A.R.A. Rahman. (2011). A Framework to Analyse The Efficiency and Governance of Zakat Institutions. Journal of Islamic Accounting and Business Research. Vol. 2 (1): 43-62. 
Wahab, N.A. \& A.R.A. Rahman. (2012). Productivity Growth of Zakat Institutions in Malaysia: An Application of Data Envelopment Analysis. Studies in Economics and Finance. Vol. 29 (3): 197-210.

Wahab, N.A. \& A.R.A. Rahman. (2013). Determinantf of Efficiency of Zakat Institutions in Malaysia: A Non Parametric Approach. Asian Journal of Business and Accounting. Vol. 6 (2): 33-64. 